\title{
透過を伴う粒子首の限界掃流条 件*
}

白戸紋 平**.大佐々 邦 久 ${ }^{* *}$ 高 奥 芳 伸**

名古屋大学 工学部 化学工学科

\section{楮曹}

希薄スラッーの浱縮，なかんずくその沈股濃縮につい ては，従来多くの報告がなされているが，汇過濃縮に関 するものは少なく，特に本報の目的としている沪材を備 えたダクトに希薄スラリーを流し，液の一部を沪材をよ ぎって透過させつつ連続的に濃縮を行なら方法について は，まったく研究がなされていない。この方法では，沪 液の透過につれて沪材面上に生成するヶークを掃流する ために必要なスラリー流速が求められなければならな い。透過を伴わない砂面上の粒子移動に関しては， Shields ${ }^{8)}$, White ${ }^{14)}$ ，岩垣 ${ }^{45}$ ，土屋 ${ }^{11,12)}$ の研究があり， 粒子が掃流され始める際の, すなわらいわゆる限界掃流 条件下の液流速および摩擦速度と粒子径との関係を理論 的ならびに実験的に求めている。

本報では透過を伴う連続汇過源縮理論の基碟的検討を 目的として，いわゆる細粗粒の範ちゅらに入る比較的大 きな粒子よりなる透過層をあらかじめ沪材面上に形成さ せ，透過を伴ら場合の限界掃流流速と粒子径ならびに透 過流速との関係について考察を試みた。この場合，㬝最 上位に存在する個々の球形粒子についての力学的平衡式 を求め，さらにそれら層表面に存在する粒子のしゃへい 俰数の概念4, 11) を用いて，粒子の限界掃流条件を表わす 式を導出した。次に，形状および密度の異なる 3 種類の 細粗粒子について実験を行なって, 実験結果と計算結果 とを比較検討した。

\section{1. 実験裝是および方法}

\section{$1 \cdot 1$ 実験社}

Fig. 1 に実験装置の配置図を示し，Fig. 2 Kは透過層 付近の詳細図を示した。透過層は，長さ $190 \mathrm{~mm}$, 幅 40 $\mathrm{mm}$ でその厚さは $10 \mathrm{~mm}$ であり，沪材は多孔板の上に 250 ×ッシュ金網を固いたるのを用いた。流速測定用ビ

* <Critical Tractive Condition of Particulate Beds under Permeation $>$

Received on November 4, 1969 化学工学協会第 34 年会 (東京 1969 年 4 月) にて発表

* Mompei Shirato, Kunihisa Osasa and Yoshinobu Takaoku (Dept. of Chem. Eng., Nagoya Univeraity, Nagoya)
トー管(2は，ダクトの上壁より㨉入され，上下に移動可 能である。また，回転可能の別のピト一管(3が流れの角 度の影響を調査するためにダクト側壁より捙入されてい る。いずれのピトー管も，内径 $1.3 \mathrm{~mm} \phi$ のステンレス 注射針製で，ダクト側壁に静圧口を配した総圧式であっ て，その先端はダクト断面の垂直中心面内で透過風の中 央上に設置した。流れ方向の観察は，層に近接した上流 部にトレーサ注入器(4)を設け，管内圧とほぼ同圧の空気 王で染料を压入して行なわれた。

使用ダクトの寸法は, 幅 $60 \mathrm{~mm}$, 高さ $42 \mathrm{~mm}$ ，全長 $2100 \mathrm{~mm}$ であって, $1300 \mathrm{~mm}$ の助走区間と, $220 \mathrm{~mm}$ の

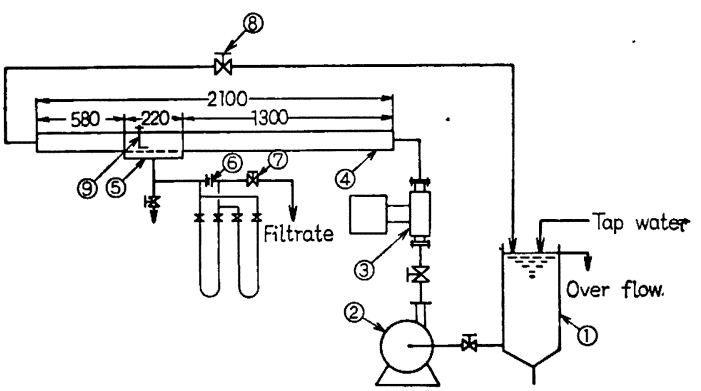

(1) Tank, (2) Pump with variable speed motor

(8) Electro-magnetic flow meter

(4) Duct $(42 \times 60 \mathrm{~mm})$, (b) Permeation section

(6) Orifice meter, (7) (8) Valve, (2) Pitot tube

Fig. 1 Schematic view of experimental apparatus

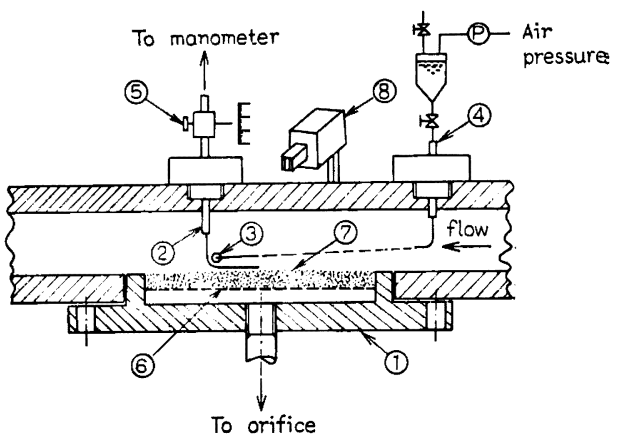

(1) Permeation section, (2)(3) Pitot tube.

(1) Tracer injection apparatus,

(6) Micro-moving apparatus,

(6) Wire mesh and perforated plate

(7) Bed. (8) Light source, (1) Pressure gauge Fig. 2 Detail of test section 
Table 1 Properties of solid materials, used

\begin{tabular}{cccc} 
Material & Soma sand & Glass beads & $\begin{array}{c}\text { Ion exchange } \\
\text { resin }\end{array}$ \\
\hline $\begin{array}{c}\text { True density } \\
{\left[\mathrm{g} / \mathrm{cm}^{3}\right]}\end{array}$ & 2.64 & 2.52 & 1.32 \\
\hline & Average particle diameter [mm] \\
\hline & 0.477 & 0.370 & 0.450 \\
\hdashline & 0.600 & 0.690 & 0.696 \\
& 0.810 & 0.810 & - \\
& 0.977 & - & 0.908 \\
& 1.50 & 1.55 & - \\
& 1.68 & - & - \\
& 1.93 & 1.81 & - \\
\hline
\end{tabular}

テスト・セクションとよりなる。また，テスト・セクシ ョンを除くダクト底部には透過部と表面状熊を同じにす る目的で, 平均粒径 $1 \mathrm{~mm}$ のガラス球をニス付けした。 水は, タンク(1)から無段変速機付きポンプ(2)により電磁 流量計(3)を経てダクトへ導かれる。ダクトおよび透過層 の流量の調節は, ポンプの無段变速機の回転数とバルブ (7)および8)を併用して行なった。また，ダクト内の水の 全流量を電磁流量計(3により，透過層を通過する流量を オリフィス(6)にって測定したっタンク(1)内の水は，実 騟中水道水を注水かつオーパフローさせることによっ て，その温度変化をほぼ $\pm 0.5^{\circ} \mathrm{C}$ 程度以内に保ちえた。

\section{$1 \cdot 2$ 実験方法}

あらかじめ対象とする粒子の厚さ約 $10 \mathrm{~mm}$ の透過圈 污浙面上に形成し，透過流速を所定値に維持しつつダ クト内液流速をしだい増加し，粒子が移動を開始する ときの流速をピト一管を用いて測定した。流速の測定に あたっては，ピト一管を透過層の上方約 $1 \mathrm{~mm}$ の所に設 定して行ない，流速分布の測定などを行なら場合には重 值上方に移動して行なった。

粒子の移動状況の観察には，透過層の中央表面部を斜 め上方の光源よりスリット状に照射しその照射部を通過 する粒子の個数を，ルーペを用いて測定した。なお，移 動状況の観察については 3-1節で詳説する。

\section{3 実験試料}

透過層形成のために使用した粒子は，ガラス球，相馬 標準砂およびイオン交換樹脂球の三種であって，その特 性值を Table 1 に表示した。各粒子はあらかじめふるい 分けされ，その粒径は適当な個数（300～500 個）を拡大 投影器を使用して測定された。

次に，粒子の移動開始について論ずる場合，水中にお ける粒子間の静止摩擦角が問題となるが，これについて は土屋 ${ }^{12)}$, Pantélopulos ${ }^{6)}$, Eagleson ${ }^{3)}$ が詳細な実験を行 なっている。すなわち，平板に対象とする粒子（粒子径 di）を二ス付けし，その上に平板上の粒子と同一または 相違なる粒径 $d_{2}$ の試料を敖き，水中で平板を徐々に傾 斜させ粒子が動き始めるときの平板の傾斜角 $\varphi$ を測定し ている。その結果, 本報の均一粒径より成る透過層粒子 の掃流を考虑する場合， $d_{1} / d_{2}=1$ であるから, $\tan \varphi=$
1.1 の値を採用した。

また，透過層の空隚率 $\varepsilon$ の佔は，普通充填でガラスお よびイオン交換樹脂のような球形粒子の場合 0.40 , 相馬 砂のような非球形粒子の場合 0.45 の値が得られている ので1,2)これを採用した。

\section{2. 球形粒子の限界掃流時における平衡条件}

Fig. 3-1 に示した均一粒径 $d_{p}$ の球状粒子群より棈成 される透過層の最上部に存在する一個の粒子を考光，そ の粒子が掃流され始めるために必要な条件について解析 する。

透過を伴わない場合について行なわれた従来の研 究4,11)では，乱流に扣ける速度変動成分が粒子の限界掃 流条件に与える影響について論及している。しかし，本 報の䢪過を伴ら掃流条件の場合，その透過流の存在が主 流の速度変動成分に与える影響は小さいものと考古, 本 報の計算では主流の平均流速 $u$ を使用した。また，透 過層表面の近傍に打ける平均液流速の位置による変化 は, 近似的に無視し得るものと仮定した。すなわち, 長 方形断面をすつダクトの底面中央部に位直する透過層は その長さが十分小さく，またダクト内の流れは乱流状態 （相当直径基準の $R e=6900 \sim 26100 ） に あ り ，$ 断面内の 流速分布はダクト壁の近傍を除いて平均化しており,さ らに透過層をよぎる液の吸引によって層表面近傍の流速 分布はいわゆる層流底層などの消失によって平均化して いると考えられる10,13)。したがって，透過層表面に存在 する粒子に作用する力としてはダクト内の主流および透 過流による抗力と粒子の重力とを考虑した。

いま，Fig. 3-1 に示した均一粒径 $d_{p}$ の不規則充媜層 の最上部の対象粒子の中心 0 と，掃流開始時にその粒子 を支持する隣接粒子との接触点 $A$ とを結ぶ直線が鉛直線 となす角を $\varphi^{4}$, 14) とする。また，限界掃流状態での粒子 に作用する力のつり合い条件を，Fig. 3-2 のように平面 上に置かれた単一球形粒子模型で表わすと次式が得られ る。すなわち, 水平方向 ( $x$ 方向) の力の平衡関係とし $\tau$,

$$
F_{f}=F_{R} \cdot \sin \theta
$$

ここに, $F_{f}[\mathrm{G}]$ は摩擦力, $F_{R}[\mathrm{G}]$ は主流による抗力, $\theta$ [radian] は主流の鈶直方向となす角である。また， $y$ 方向については

$$
F_{N}=F_{R}{ }^{\prime}+F_{R} \cos \theta
$$

ここに, $F_{N}[\mathrm{G}]$ は垂直抗力, $F_{R}{ }^{\prime}[\mathrm{G}]$ は粒子に働く重力 および透過流による抗力の和である。また、一般に次式

$$
F_{f}=F_{N} \cdot \tan \varphi
$$

の関係があるので, Eqs. (1), (2) および (3) より $F_{f}$, $F_{N}$ を消去乙整理すると粒子の限界掃流条件を与える次 式が導かれる。 


$$
F_{R}\{(\sin \theta / \tan \varphi)-\cos \theta\}=F_{R}{ }^{\prime}
$$

上式中の $F_{R}$ は, 単一球形粒子模型について次式で表わ される。

$$
F_{R}=\frac{\rho}{2 g_{c}} C_{D} u^{2} \pi\left(\frac{d_{p}}{2}\right)^{2}
$$

ここに, $\rho\left[\mathrm{g} / \mathrm{cm}^{3}\right]$ は液密度, $C_{D}[$ 一 $]$ は主流方向の流速 uに基つくく抗力係数である。

次に，充塓層の上部に存在する粒子が他の粒子の存在 によって受ける影響を考虑するに，Fig. 3-1 に扎いて上 流にある粒子群が主流を遮ぎる影響によって対象とする 粒子表面の上部（斜線部）のみが主流の効果を受け，乙 たがって主流による流体抗力 $F_{R}$ は単一球形粒子の及あ るとした場合の Eq. (5) より減少する。その減少を近似 的に球の投影面積の減少（主流に対して露出している球 表面の投影面積）に㷌し得るとすれば，Eq. (5) は次式 のように書き換えられる。

$$
F_{R}=\psi \frac{\rho}{2 g_{c}} C_{D} u^{2} \pi\left(\frac{d_{p}}{2}\right)^{2}
$$

ここに， $\phi[$ 一] はいわゆる粒子のしゃへい（遮蔽）係 数4,11)である。また，粒子表面の下部では透過流による 効果が支配的であると考えられ，よって $F_{R}{ }^{\prime}$ は近似的に 次式で表わしらるとする。

$$
F_{R}{ }^{\prime}=\frac{\pi}{6} \frac{g}{g_{c}}\left(\rho_{p}-\rho\right) d_{p}{ }^{3}+\frac{\rho}{2 g_{c}} C_{D v} v^{2} \pi\left(\frac{d_{p}}{2}\right)^{2}
$$

ここに, $\rho_{p}\left[\mathrm{~g} / \mathrm{cm}^{3}\right]$ は粒子密度, $C_{D_{v}}[$ 一] 摆内の透過 真流速 $v[\mathrm{~cm} / \mathrm{sec}]$ に基づく抗力係数である。上式右辺 の初項は粒子に働く重力, 第二項は透過流に上る流体抗 力を示す。この抗力は粒子上部に主流が作用して㧊り， したがって単一球形粒子の透過抗力とはややその值を異 にすると推察されるが，ここでは近似的に球形粒子の抗 力式を用いてある。

また，主流の鉛直方向となす角 $\theta$ は，主流方向の平均 流速 $u$ と層表面での見かけ透過速度 $v_{a}$ との間のベクト ル関係より求められ，また $v_{a}$ と $v$ との間には $v_{a}=\varepsilon v の$ 関係がある。したがって，次式

$$
\left.\begin{array}{l}
\sin \theta=\sqrt{u^{2}-v_{a}^{2}} / u=\sqrt{u^{2}-\varepsilon^{2} v^{2}} / u \\
\cos \theta=v_{a} / u=\varepsilon v / u
\end{array}\right\}
$$

が成立する。

Eqs. (6)，(7) および（8）を Eq. (4) に代入して主流

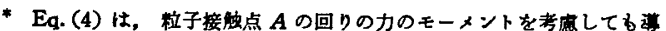
き5る。すなわち, 点 $A$ 上り， $F_{R}, F_{R^{\prime}}$ に下した垂線の長さは, そ れぞれ $\overline{A P_{1}}=\left(d_{p} / 2\right) \cdot \sin (\theta-\varphi), \overline{A P_{2}}=\left(d_{p} / 2\right) \cdot \sin \varphi$ である。し たがって,モーメントの成係式は $F_{R} \cdot\left(d_{p} / 2\right) \cdot \sin (\theta-\varphi)=F_{R^{\prime}}$. $\left(d_{p} / 2\right) \cdot \sin \varphi$ となり, Eq. (4) 飞一致する。

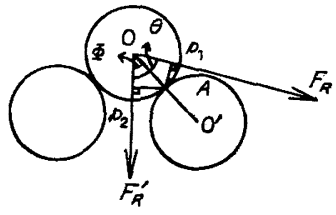

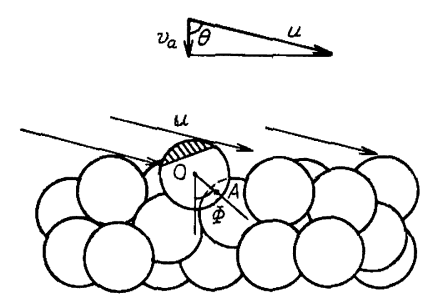

Fig. 3-1 Model of flow pattern for a representative particle

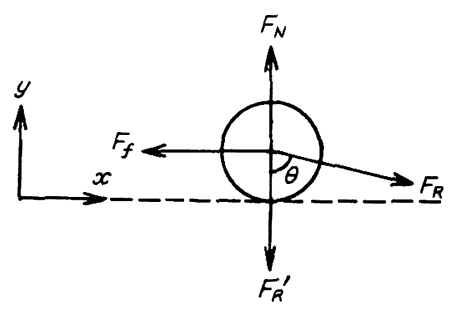

Fig. 3-2 Force balance for a single particle model

のレイノルズ数 $R e_{p}[-]\left(=d_{p} u \rho / \mu\right)$ について整理する $\varepsilon$, 次式を得る。

$$
\left.\begin{array}{r}
C_{D}{ }^{2} R e_{p}{ }^{4}-K_{1} C_{D}{ }^{2} \operatorname{Re}_{p}{ }^{2}-K_{2} C_{D} R e_{p}-K_{3}=0 \\
K_{1}=\left(\varepsilon \operatorname{Re}_{v}\right)^{2}\left(1+\tan ^{2} \varphi\right) \\
K_{2}=\left(\frac{2 \varepsilon}{\psi}\right) \tan ^{2} \varphi \operatorname{Re}_{v}\left\{\frac{4}{3}\left(\frac{\rho_{p}}{\rho}-1\right)\left(\frac{\rho}{\mu}\right)^{2} g d_{p}^{3}\right. \\
\left.+C_{D v} R e_{v}{ }^{2}\right\} \\
=\left(\frac{2 \varepsilon}{\psi}\right) \tan ^{2} \varphi R e_{v}{ }^{3}\left\{\frac{4}{3}\left(\frac{\rho_{p}}{\rho}-1\right) \frac{1}{F r^{2}}+C_{D v}\right\} \\
K_{3}=\left(\frac{\tan \varphi}{\psi}\right)^{2}\left\{\frac{4}{3}\left(\frac{\rho_{p}}{\rho}-1\right)\left(\frac{\rho}{\mu}\right)^{2} g d_{p}{ }^{3}\right. \\
\left.+C_{D v} R e_{v}{ }^{2}\right\}^{2} \\
=\left(\frac{\tan \varphi}{\psi}\right)^{2} \operatorname{Re}_{v}{ }^{4}\left\{\frac{4}{3}\left(\frac{\rho_{p}}{\rho}-1\right) \frac{1}{F r^{2}}+C_{D v}\right\}^{2}
\end{array}\right\}
$$

ここに, $R e_{v}$ は透過流のレイノルズ数 $\left(=d_{p} v \rho / \mu\right), F r$ は $F r=v / \sqrt{g d_{p}}$ で定義されるフルード数である。

さらに，本報に拈ける実験条件 $\left(R e_{p} 5800\right)$ を考慮し て, Eqs. (9), (10) に和ける抗力係数 $C_{D}$ および $C_{D v}$ K は共に Schiller \& Naumann" の実験式

$$
C_{D}=(24.0 / R e)\left(1+0.15 R e^{0.687}\right) \quad 0<R e<800
$$

を用いた。ここに，Re は主流または透過流の粒子レイ ノルズ数である。Eq. (11) を Eq. (9) に代入して整理す ると $R e_{p}$ に関する超越方程式が得られる。

Eq. (9) において, $\rho_{p}, \rho$ および $\mu$ 既知の場合，粒径 $d_{p}$ を助变数として $R e_{v}$ vs. $R e_{p}$ の計算值を Fig. 4 に示 した。方程式の解法には Newton の遂次近似法9を適用 し，その計算には電子計算機を使用した。Fig. 4 にはガ ラス粒子の場合を例示してあるが，四中の実線はしゃへ 


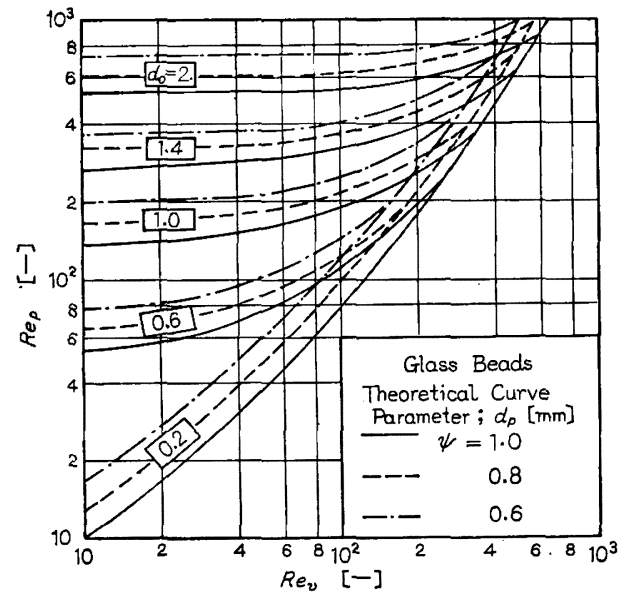

Fig. $4 \quad R_{p}$ vs. $\operatorname{Re}_{v}$ (Glass beads)

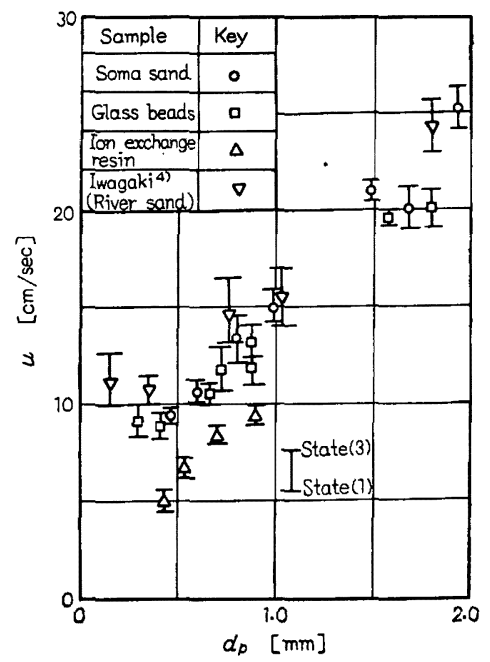

Fig. 5 Critical tractive velocity $u$ vs. particle diameter $d_{p}$ without permeation

い効果のない場合，すなわち $\psi=1$ の場合の計算値，他 の曲線はしゃへい係数 $\psi=0.8,0.6$ とした場合の値であ る。ある粒径において求められた曲線より上の領域で は，その粒子の掃流が可能であり，曲線より下の領域で は粒子の静止状態が維持され, その曲線が粒子の限界掃 流条件を与える。

\section{3. 実験結果および考察}

\section{1 限界淿流流速と透過流速との関係}

粒子の限界琭流条件を論ずる場合，特に問題となるの は，粒子移動の限界としていかなる状態を採用するかで ある。岩垣ら")は，限界として採用し得る状態として， （1）粒子が時々移動する状態，(2）粒子が全面的に移動 する状態（3）何秒間に何個ずつ連続的に移動すると観

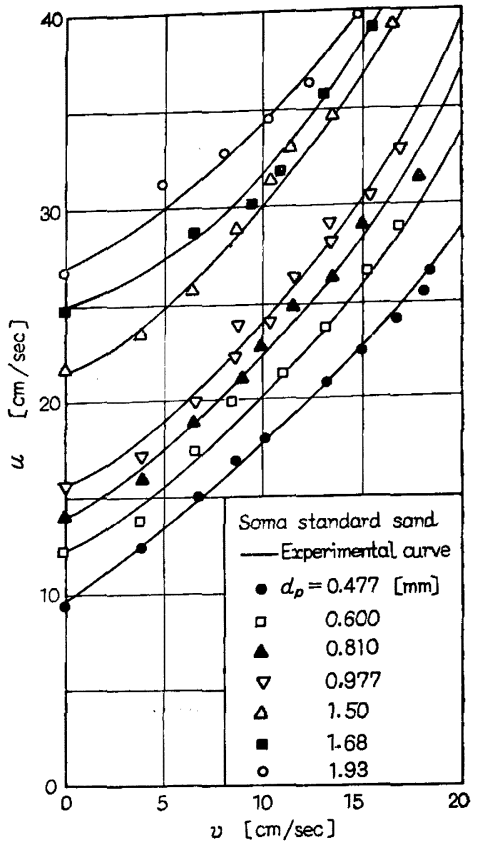

Fig. 6 Critical tractive velocity $u$ vs. permeation velocity $v$ (Soma sand)

察できるような（1）と（2）との中間的状態の三状態が 概念的に考えられるとしている。（1）の状態は，透過層 表面の特に移動しやすい不安定な粒子に関するるのて, 㬝表面の粒子全体の平均的な限界とするには問題があろ う。したがって，(2) または（3）の状態を粒子の移動 限界として採用するのが適当と思われるが，(2）の状態 ではかなりの量の粒子が移動するので透過表面に㧊忛る 平均的な粒子の移動開始といら観点から，(3) のいわゆ る中間的状態を移動限界として採用したす。本報におけ る中間的状態での粒子の移動個数は，粒子径によっても 相違するか，透過層幅 $4 \mathrm{~cm}$ 当り最大 40 個 $/ \mathrm{min}$, 最小 6 個/min とした。この.中間的状態での粒子移動状態の $u$ による变化はきわめて鋭敏であって，uの值を \pm 2.0 $\mathrm{cm} / \mathrm{sec}$ 変化させることによって，粒子の静止あるいは 全面的移動の状態が見られた。

透過を伴わない場合の充媜層粒子径 $d_{p}$ と限界掃流流 速 $u$ との実験結果を Fig. 5 に示した。図中の岩垣》の結 果は，正方形ダクト $(5 \times 5 \mathrm{~cm})$ 内の速度分布に関する彼 の実鈳データの砂面上 $1 \mathrm{~mm}$ での流速であり，Fig. 5 に は（1）粒子が時々移動する状態 (図中，State (1))，(3) 中間的移動状態 (図中, State(3)) の両者の場合を示し た。著者らの実験結果は，相馬砂，ガラス球およびイオ ン交換樹脂球について示してあるが，図ょり明らかなと 捄り密度の小さいイオン球の限界流速は，他の二試料よ り幾分小さく，また密度が注、ま相等しく粒子形状の異な る相馬砂とガラス球との值の间には相違が見られない。 


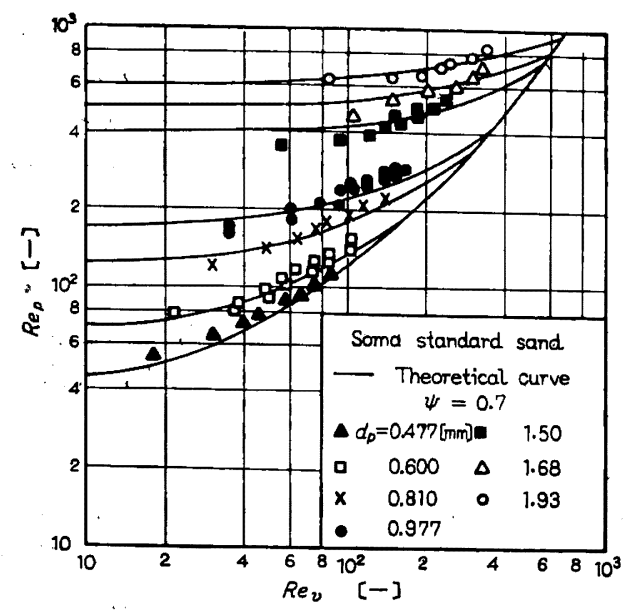

Fig. 7 Rep vs. $R e_{v}$ (Soma sand)

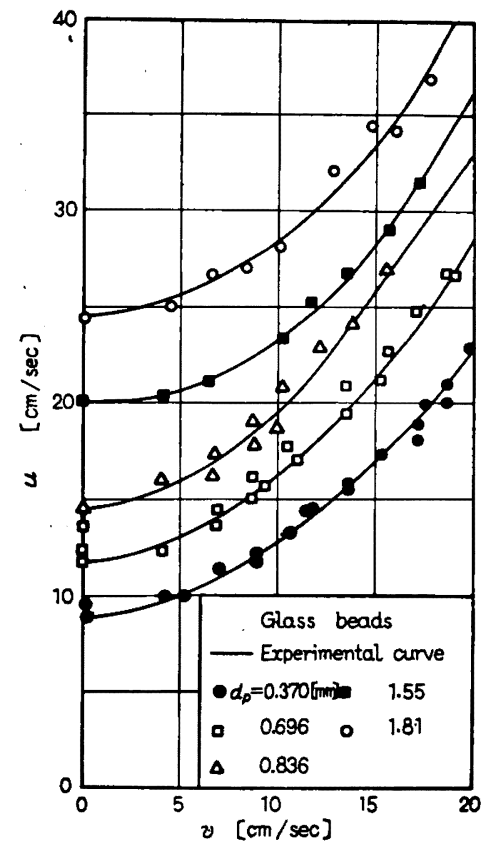

Fig. $8 u$ vs. $v$ (Glass beads)

相馬砂の充塓層についての透過を伴う場合の実験結果 を，粒径 $d_{p}$ を助変数として透過の真流速 $v$ 対状態 (3) К淤る限界掃流流速 $u$ として Fig. 6 亿示した。また， 実験値と計算值との比較のために，透過レイノルズ数 $R e_{v}$ 対主流レイノルズ数 $R e_{p}$ を Fig. 7 に示した。Fig. 7 К为ける実線は，しゃへい保数 $\phi=0.7$ として Eq. 9 より計算されたものであり, $\psi=0.7$ の值は, Fig. 4 に示 したように種々の $\varphi$ の値について曲線を求め, 粒径, 試 料の種類によらず実験値と最も良く一致した値として得 たすのである。罒より明らかなとおり，粒径 $d_{p}$ の大き い場合には，粒子に働く重力の影繁が大きく透過流の効 果が小さいため曲線は平坦に近いが，粒径の小さい範囲

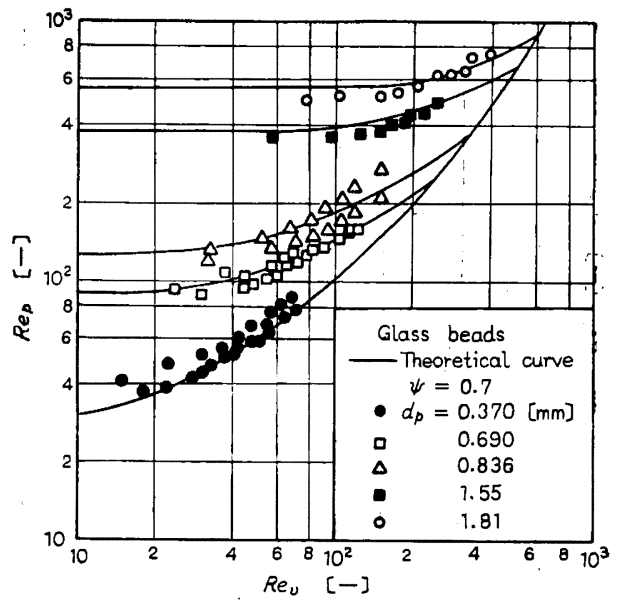

Fig. $9 \quad \operatorname{Re}_{p}$ vs. $R e_{v}$ (Glass beads)

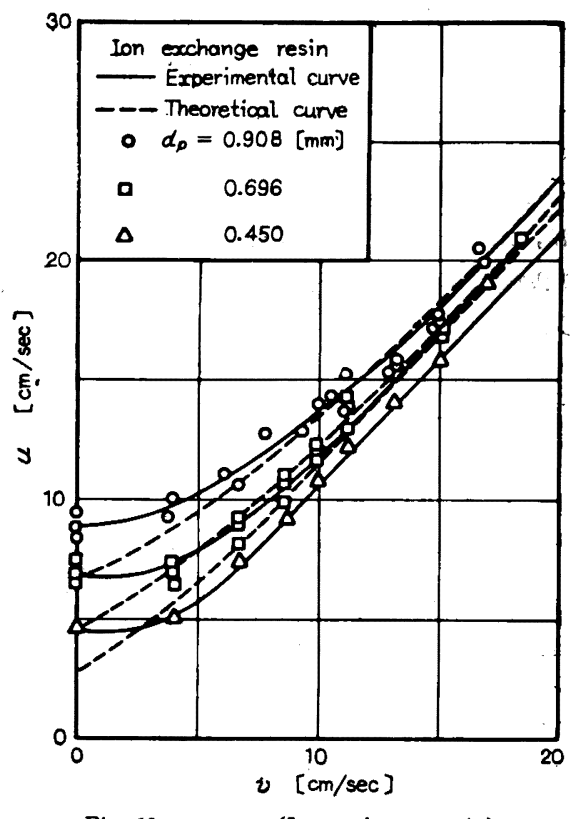

Fig. $10 u$ vs. $v$ (Ion exchange resin)

では透過流による影響が大きい。Figs. 8,9 にガラス球 の場合の実験結果を，Figs. 10, 11 にイオン交換樹脂球 についての結果を示した。イオン交換樹脂球は，その密 度が $1.32 \mathrm{~g} / \mathrm{cm}^{3}$ と小さく，したがって粒径の大きい範 囲においても透過流の影響が大きく表われている。ガラ ス球，イオン交換樹脂球のような球形粒子の場合も計算 値はすべて $\phi=0.7$ としてある。

\section{$3 \cdot 2$ ᄂゃへ係数}

前述のごとく，しゃへい係数 $\phi$ とは対象とする粒子が 隣接する他の粒子群によって流れをしゃへいされる結果 として, 主流方向の流体抗力が減少する効果を示すすの である。したがって，透過を伴う場合その值は流れの角 度 $\theta$ によって変化することが考えられる。本実験の場 


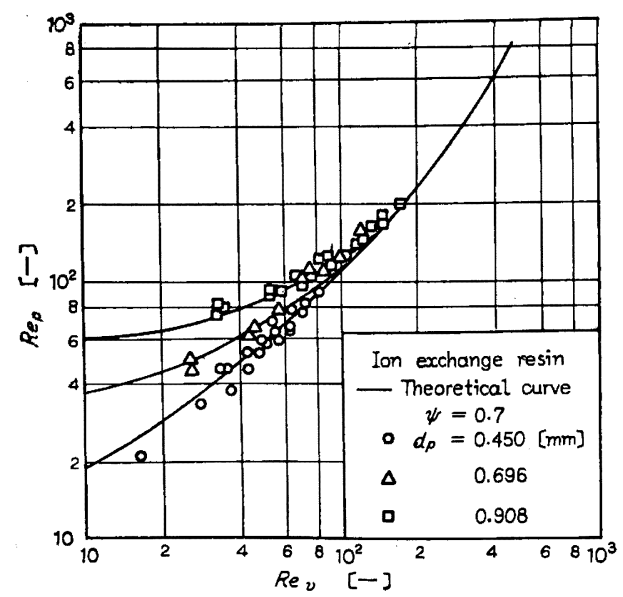

Fig. $11 R e_{p}$ vs. $R e_{0}$ (Ion exchange resin)

合，透過流速は比較的小さく，実測結果によれば $\theta$ はお おむね 80 度近傍の値を示し， $\phi$ を一定値 0.7 として取 り扱った。岩垣らはは透過を伴わない水平流の場合，実 験的に $\phi=0.4$ を得ている。本報では, 主流方向が透過 層に対して傾斜しているため対象粒子のしゃへいされる 割合は，水平流に比へてて小さくその結果 $\psi$ の值は透過を 伴わない場合に比べ大きくなると考光られる。また, イ オン交換樹脂球の実験結果 Fig. 10 に特に顕著に見られ
る現象であるが、透過流速 0 付近の実測値が $\phi=0.7$ と した計算値より㣂倚を示している。これは，透過流速を 減少せしめた揚合值斜流から水平流へと移行し， $\psi$ の值 が 0.7 から隇少する過渡状態を示するのと思われる。

\section{結言}

流通式汇過濃縮の研究を目的としてて，透過を伴う場合 の粗細粒子関する限界掃流条件を考察し，以下の結果 を得た。

（1）一様流れ場内におかれた粒子充埧層の表面に存 在する代表粒子に関する力学的平衡式を求め,さらに隣 接する粒子がその代表粒子に与える影響を表わすしゃへ い係数の概念を用いて，粒子の限界掃流条件式を導出し た。この式を用いて，充填粒子の直径，密度，および液 特性が与えられた場合，任意の充填層透過流速に対して 限界掃流流速を求めることができる。

（2）三種の粗細粒子（粒子径 $0.4 \sim 1.95 \mathrm{~mm}$ ）飞関 する実駼値によれば，実験值はしゃへい係数 $\phi=0.7$ と して得られる計算値と比較的良い一致を示した。

[付 記]本研究は文部省科学研究費 (一般研究, 課題番号 B-8726）の補助を受けた。ここに，厚く感謝の意を表わす。

\section{Nomenclature}

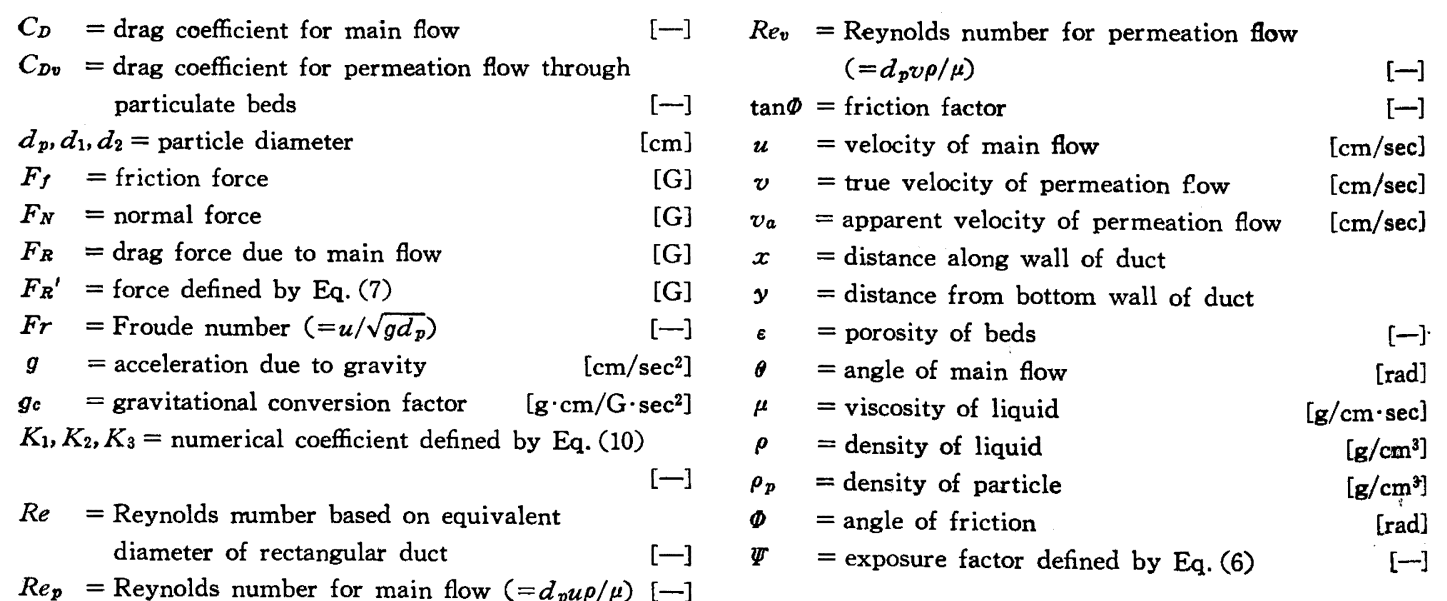

\section{Literature cited}

1) Brown, G. G. : "Unit Operation", 214, John Wiley \& Sons Inc. (1950)

2) "Kagaku-Kogaku Binran", 669, Maruzen (1963)

3) Eagleson, P.S. and R.G. Dean : Proc. A. S. C. E., 85, HY 10, 53 (1959)

4) Iwagaki, Y.: Trans. of J. S. C. E., 41, 1 (1956)

5) Iwagaki, Y.: ibid., 42, 22 (1956)
6) Pantelopulos, L.: Proc. of 7 th General Meeting of I. A. H. R., D 30-1-24 (1957)

7) Schiller, L. V. and A. Naumann: Ver. dtsch Ing., 73, 318 (1933)

B) Sields, A. : Mitteilungen der Preussian Versuchsanstalt for Wasserbau u. Schiffbau, Heft 26 (1936)

9) Sugiyama, S. and I. Takahashi: "Suchi Kaiseki", 78, Hi- 
rokawa Shoten (1966)

10) Terrill, R.M.: Appl. Sci. Res., A 17, 204 (1966)

11) Tsuchiya, Y.: Trans. of J. S. C. E., 94, 13 (1963)

12) Tsuchiya, Y. : ibid., 98, 1 (1963)
13) Wasan, D.T. and S.S, Randhava: Chem. Eng. Sci., 24, 595 (1969)

14) White, C. M.: Proc. Roy. Soc. (London), A 174, 322 (1940)

\section{高粘性液の摚拌槽における循環時間分布*}

一らせん帯翼，錨型翼，らせん軸翼について—

\author{
大島 栄 次**.弓 削…耕**** \\ 東京大学 工学部 化学工学科**
}

\section{粕言}

擋拌槽飞批ける高粘性流体の混合は，せ几断混合と対 流湿合により行なわれると考光ることができる。このら ち対流混合は槽内を流体か流動する径路すなわちフロー パターンとその径路をどのような速さで循環するかとい ら循環時間で決められるする。

この対流混合に着目し，擋拌槽で高粘性液をかい、型翼 およびタービン型翼を用いて擋拌した場合の流動状態と 循環時間分布についてはすで明らかにした7》。しかる に擋拌レイノルズ数の低い領域ではかい型翼・タービン 型翼を用いたときには刘流混合が局所的になり効率よい 混合が行なわれなくなるので，高粘性液を混合するのに はらせん帯翼・らせん軸翼が適していると考兄られてい る゙。これらの翼による混合については混合時間と所要 動力の測定を主眼とした研究が行なわれているが1 槽内の対流混合に着目した研究は少ない。

そこで著者らはらせん帯翼，錨型翼，らせん軸翼を用 いて高粘性液を擋拌したときの流動状態と循噮時間の分 布を測定した。これらの翼で混合した場合には，かい型 翼やタービン型翼の場合よりもせん断混合と対流混合と の区別が明確でなくなるが，対流混合を把握できる範团 内で，上記 3 種類の翼について流動状態，循謤時間分布 と液の粘度, 回転数, 液深との関係を比較検討した。

\footnotetext{
* <Circulation Time Distribution of Viscous Liquid in a Mixing Vessel -Helical Ribbon Type, Anchor Type and Helical Screw Type Impellers $\longrightarrow$ Received on December 12, 1969 化学工学協会第 3 回秋车大会（1969 年 10 月大阪）にて一部研究発 表

** Eiji O'Shima (Dept. of Chem. Eng.,Univ, of Tokyo, Tokyo, Japan)

*** Koh Yuge (東 $\vee($ 株) Toray Industries Inc.)
}

\section{1. 実験装置およひ測定方法}

実験装置は槽内径 $212 \mathrm{~mm}$ の円筒形平底の擋拌槽安用 い，擋拌翼は Fig. 1 に示すようならせん帯翼および錨 型翼と Fig. 2 に示すらせん軸翼とドラフトチューブと

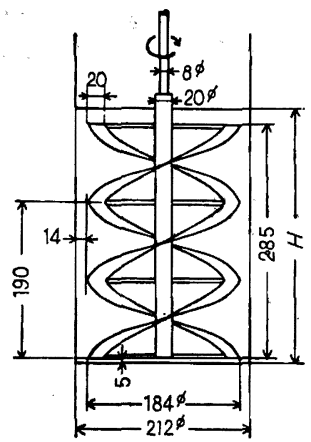

(a) Helical ribbon type

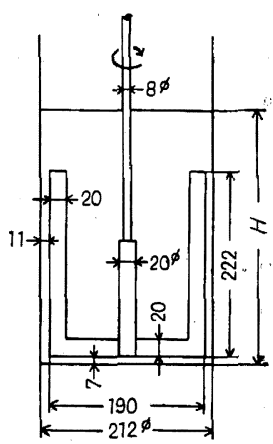

(b) Anchor type
Fig. 1 Mixing vessel and mixing impellers

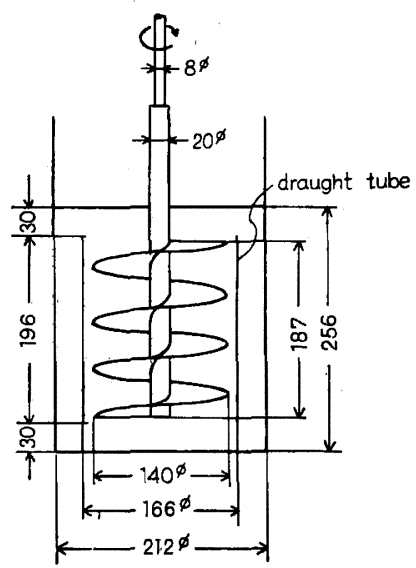

Fig. 2 Mixing vessel and helical screw type impeller with draught tube 
$Q$ 関数を用いる Wilson パラメータの決定法 (宮原是 Q 单村和彦. 佐渡友秀夫, 化学工学, 34, $739 \sim 744$ 中・北村和、関のピークから Wilsonのパラメータを決定する (1970) 济ラメータを求めるチャートと, 得られたピークか

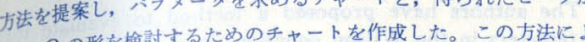
らケ,Q

都らのカ法をと゚ソゼンーエタノール系 (正に偏倚)，アセトンー 吅ホルム系（真に偏倚）に適用しはぼ满足なバラメータを決定 と方ことを確認した。

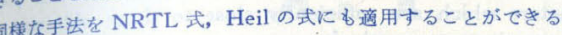

に流管のない多孔板上の液停滞量（高橋照男・須藤 流官の男, 化学工学、 34, 744 750 (1970)) 溢洴 管の†い、攵液向流型の段塔の棚段上飞形成される泡沫層の流動機楼 明らがする目的で, 多孔板上の液停滞量に及ばす多孔板形状, 德作因子などの影響を考察して夜停滞量の推算式をえた。さらに 林空気系の実験によって諸因子間の相関関係を明らかにし, 推算 蝴の倸数値を決定した。

2成分混合液体の核沸騰熱伝 達 (武田紘雄・早川豊彦. 藤田重文, 34, 751〜755 (1970)) ×タノール, エタノ ル、アセトン、メチルエチルケトン招よびこれらの水溶液についた

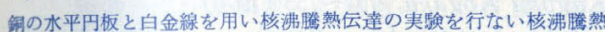
云達保数を求めた。实験結果を次元解析により整理し次の無次元实 験式を得た。

核弗睊末発達領域 $(25<R e<150)$

$$
j_{H} \equiv S t \cdot P r^{2 / 3}=7.50 \times 10^{-2} R e^{-0.80} \cdot \Pi^{0.25}
$$

輆沸腾領域 $(150<\operatorname{Re}<5000)$

${ }_{1 H} \equiv S t \cdot P r^{2 / 3}=1.00 \times 10^{-2} R^{-0.35} \cdot \Pi^{0.25}$

謵家の実験結果を式 (1), 式 (2) とよって整理した結果, 核涨 吰未発達領域では多少のばらつきが認められたが、核沸滕領域では 良い一致を示した。

連続向流抽出塔における分散滴径分布の影響(江口 竹 塩田三郎・森 素明, 化学工学, 34, 755 762 (1970)) 速統相と向流に接触する滴径分布の存在する分散相とつ間で物質移 䡃が進行する場合について, その数式モデルを提出し, 水一トル ン滴系を用いた液夜スプレ塔の实験結果より得られ九諸因子の知見 を用いて数值实験を行なった。滴径分布のために，物質移動倸数， 界面皘肪よび接触時間にも分布を生ずるが，接触時間分布は界面䅱

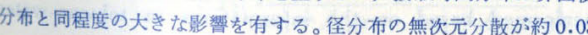
以下ならば, 滴群を均一径滴群とみなしてプラグ流をたす分散相流 としての取报いができる。
二重管式気泡塔の物質移動について（菜池 淳・只木枮 力·前田四郎, 化学工学, 34, 762 767 (1970)) 二重 管式気泡塔は内管および外管とからなる垂直二重管で, 吸取液が㺺 状部から内管内へ偱環し、内管内では気泡之並流接触している。こ の装置に扰ける物質移動を表わすために，被吸収ガスがある积度 解している液と気泡が接触して化学吸収が起こると考劣, 連続的に 発生する気泡からの物質移動モデルを提出した。このモデルはペン ゼン・塩素系の吸収実験結果を大略表わすことができた。

Fan nozzle によるスプレーの粒径分布の分散について (松本史朗 - 池田三樹夫 ·高島洋一，化学工学, 34, 768 772 (1970)) Fan nozzle による微粒化実験から, 液膜の分 裂距離と波長の分布な測定し，それらが生成される液滴の粒径分布 にいかなる影響を与えるかを，二つの兴粒化モデと対比して考察 した結果，粒径分布の分散は液膜の分裂距離，波長の分布によるの

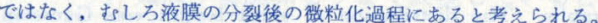
なお，液膜の分裂距離の分布は正規分布，波長の分布は対数正規分 布を示すことがかかった。

透過を伴う粒子層の限界掃流条件 (白戸紋平・大佐々邦 久-高奥芳伸, 化学工学, 34, 773 779 (1970)) 流通

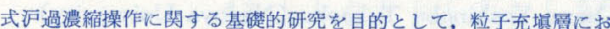
ける透過を伴 5限界掃流条件を考察した。粒子の移動に関する限界 掃流式は, 粒子径拉よび密度, 液特性ならびに粒子相互間の効果を 表わす遮敬保数の影響を考虏して，粒子の力学的平衡関係上り道か れた。

異なる三種の粒子層について得られた実測值は、計算值とかなり 良い一致を示し，粒子特性四知の場合与之られた透過流速下での䊉 子の限界掃流流速が計算できる。
高粘性液の擋拌槽における循環時間分布一らせん带 翼，錨型翼，らせん軸翼について一（弓削 耕・大島 栄次. 化学工学, 34, 779 785 (1970)) 擋拌槽内の対 流混合は摚拌翼の作用により生ずる循鲾流によって行なわれ，これ

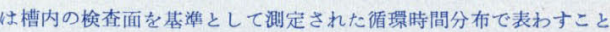
がでる。この観点から, 高粘性液をらせん帯翼, 銷型翼, らせん 㜞翼て摚拌したときの循環時間分布を道跡粒子法で測定した。その 分布を槽内の流動状熊と対応させ 2 つの関数型で近似し，翼，粘 度, 回転数などの因子との関係を娭討しとくに翼，絬度との特䍃 的な関倸を明らかとした。

<寄書

Wilson, Heil, NRTL 式中のパラメーターについて (長田 勇·太田建彦, 化学工学, 34, 785 787 (1970)) Wilson, Heil, NRTL 式中のエネルギーバラメーター間の相互関 倸について，三成分系を構成与る各二成分系化着目して一考察を行 なった。その結果それらの推算式は半経験的な式として报った方が 適当であることを確めた。また NRTL 式中のバラィーター $\alpha_{12}$ の 温度传存性と $\alpha_{12}$ の值が気相組成 $y$ と蒸気压 $P$ に及活す影管を榆 討した。 
Circulation Time Distribution of Viscous Liquid in a Mixing Vessel Herical ribbon type, anchor type and herical screw impellers $\mathrm{K}$. Yuge and E. O'Shima (University of Tokyo) Kagaku Kögaku, 34, 779 785 (1970)

It is considered that the convective flow mixing in a vessel is achieved by circulation flow, which is caused by the impeller rotation. This convective flow mixing can be characterized by circulation time distribution which is measured on the basis of a measuring plane in a vessel.

From this point of view, the circulation time distribution of viscous liquid was measured with the use of a small tracer particle. Three types of impellers, helical ribbon type impeller, anchor type impeller and helical screw type impeller with a draught tube were used in the experiments. It was found that the circulation time distribution function can be reprseented by the sum of two mathematical function, i.e trigonometrical and exponential functions, ac. cording to the flow patterns in a vessel. The shape of the distribution function depends on the shape of impel thill and opeed of revolution.

\section{$<$ Short Communication $>$}

A Note on the Parameters in the Wilson, Heil, and NRTL Equations. Isamu Nagata and Tatsuhiko Ohta (Kanazawa University)

Kagaku Kōgaku, 34, 785〜787 (1970)

In the Wilson, Heil, and NRTL equations, the mutual relationship among three set of energy parameters obtained from binary systems which compose a ternary system is discussed.

Numerical results are presented concerning the effect of the temperature on the nonrandomness constant $\alpha_{12}$.
Mass Transfer in the Double-tube Bubble Column. A. Kikuchi, T. Tadaki and S. Maeda (Tohoku University)

KagaKu Kögaku, 34, 762 767 (1970)

The double-tube bubble column is one of the gas-liquid contacting apparatus consisting of two concentric vertical tubes. The absorbing liquid in the inner tube flows up concurrently with bubles, and circulates down through concurren The appatus was tesed for The apparatus was tested for chlorination of benzene catalyzed by ferric chloride, under the condition of vary. ing gas concentration, catalyst concentration and others. Theoretical equations on solute concentration and mass transfer rate were derived, by assuming that chemical absorption by liquid containing the solute takes place during the time when liquid contacts with the bubble, and the solute simply reacts with the liquid except that dura. tion of the time.

Experimental values on chlorine concentration in ben zene fairly coincide with theoretical ones.

On the Variance of Sprayed Drop Size Distribution by a Fan Nozzle. S. Matsumoto, M. Ikeda and Y. Takashima (Research Laboratory of Nucl. ear Reactor, Tokyo Inst. of Tech).

Kagaku kōgaku, 34, 768 772 (1970)

The length of liquid sheet from a fan nozzle and its fluctuation were observed by taking numerous strobo photographs. The distribution of sheet length was Gaussian one, and its variance was very small as compared with one, and its variance was very small as compared with the variance of drop size distribution. Therefore, we not be due to the fluctuation of liquid sheet length from not be due to
the fan nozzle.
Critical Tractive Condition of Particulate Beds under Permeation. Mompei Shirato, Kunihisa Osasa, Yoshinobu Takaoku (Nagoya University) Kagaku Kōgaku, 34, 773 779 (1970)

In order tc afford a basic mathematical tool for the socalled filter-thickening operation, the critical tractive condition for particulate beds under permeation is studied.

On the basis of kinetics for a particle in the uppermost layer of beds, the critical tractive equation is derived in terms of the particle diameter $d_{p}$, its density $\rho_{p}$, the liquid characteristics atio of the projected area

Experiments were executed by using three kinds of materials forming beds. Reasonable coincidence between the theory and experiments are obtained.
Evaluation of the Wilson Parameters by Q Fun tamura and $\mathrm{H}$. Sadoton (Mitsui Toatsu Chemical Inc.)

Kagaku Kōgaku, 34, 739〜744 (1970)

The authors have proposed a method to evaluate th parameters in the Wilson equation from $Q$ function, and these charts, precise parameters can be determined without difficulty.

Applying the proposed procedure to benzene-ethanol (positive deviation) and acetone-chloroform (negative de. viation) binary systems, we have determined the para. meters which are sufficiently close to those obtained more rigourous methods

Liquid Hold-up on a Perforated Plate without Downcomer. Teruo Takahashi, Sho Sudo (Okaya. ma Univ.) and Mitsuo Tanaka(Okayama College of Sci.)

Kagaku Kōgaku, 34, 744 750 (1970)

In order to clear the flow mechanism of the foaming layer on a tray without downcomer, the liquid hold-up on a perforated plate were considered theoretically and ex. perimentally, From the correlation between tray shapes, gas and liquid rates, physical properties of both fluid and pressure drop of gas through the foaming layer, a theoret. ical equation for the liquid hold-up on a perforated plate was derived. And also, some coefficients in this equation were determined by the experiment of water-air system

Boiling Heat Transfer Coefficients in Binary Liquid Mixtures. Hiroo Takeda, Toyohiko Haya kawa and Shigefumi Fujita (Tokyo Inst. of Tech. Kagaku Kōgaku, 751 755 (1970)

Boiling heat transfer coefficients on a horizontal copper plate and a platinum wire were measured experimentally for five pure liquids and ten liquid mixtures. These liquids were water, methanol, ethanol, acetone, methylethylketone were water, methanol, ethanol, acetone, methlethy MeOHand $\mathrm{H}_{2} \mathrm{O} \cdot 3,10,50 \mathrm{~mol} \% \mathrm{EtOH}-\mathrm{H}_{2} \mathrm{O} ; 3,50 \mathrm{~mol} \%$ Acetone- $\mathrm{H}_{2} \mathrm{O}$ :

$\mathrm{H}_{2} \mathrm{O} ; 3,10,50 \mathrm{~mol} \% \mathrm{Et}$.
$3,50 \mathrm{~mol} \% \mathrm{MEK}-\mathrm{H}_{2} \mathrm{O}$ )

All these experimental date were correlated by an equa. tion derived from dimensional analysis. It was found that this equation was in good agreement with the other data of pure liquids and binary liquid mixtures on several heating surfaces $(\mathrm{Cu}$-plate, $\mathrm{Cr}$-plate, Brass pipe, $\mathrm{Pt}$-wire

The Effect of the Diameter Distribution of Dis persed Droplets in a Continuous Countercurrent Extraction Column. Wataru Eguchi, Saburo Sh ota and Motoaki Mori (Kyoto University)

Kagaku Kōgaku, 34, 755 762 (1970)

For countercurrent flow and solute transfer between : continuous phase and drop population of size distributio the mathematical model was proposed and computation performed based on the informations in toluene-wa system.

The distributions of mass transfer coefficient, interfac area per unit volume and contacting time of droplet rest from the size distribution, but contacting time distributio is a potent influence in the same degree as the interfac area.

If the dimensionless variance of size distribution is 1 than about 0.03 , a drop population can be treated as of uniform size. 